Jurnal KIBASP (Kajian Bahasa, Sastra dan Pengajaran)

Volume 1, Nomor 1, Desember 2017

e-ISSN : 2597-5218

p-ISSN : 2597-520X

DOI: https://doi.org/10.31539/kibasp.v1i1.64

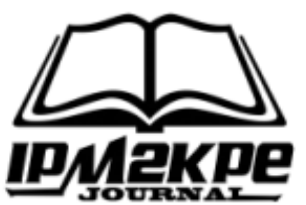

\title{
HUBUNGAN ANTARA PENGETAHUAN KEBAHASAAN DENGAN KEMAMPUAN MENULIS NASKAH DRAMA BERDASARKAN \\ PENGALAMAN PRIBADI SISWA KELAS XI SMA NEGERI 1 LUBUKLINGGAU
}

\author{
Inda Puspita Sari \\ Program Studi Pendidikan Bahasa dan Sastra Indonesia, STKIP-PGRI Lubuklinggau \\ Indashop21@gmail.com
}

Submit, 15-11-2017 Accepted,31-12-2017 Publish,31-12-2017

\begin{abstract}
ABSTRAK
Tujuan penelitian ini untuk mengetahui hubungan pengetahuan kebahasaan dengan kemampuan menulis naskah drama berdasarkan pengalaman pribadi siswa kelas XI SMA Negeri 1 Lubuklinggau. Penelitian ini menggunakan metode deskriptif korelasi. Pengumpulan data dilakukan dengan teknik tes dengan dua variabel. Variabel dalam penelitian ini terdiri dari variabel $(X)$ pengetahuan kebahasaan $(Y)$ kemampuan menulis naskah drama berdasarkan pengalaman pribadi.Untuk mengetahui bagaimana hubungan antara pengetahuan kebahasaan dengan kemampuan menulis naskah drama berdasarkan pengalaman pribadi siswa kelas XI SMA Negeri 1 Lubuklinggau, maka dilaksanakan uji statistik dengan menggunakan rumus Product Moment angka kasar. Pengujian hipotesis dengan membandingkan besarnya $r_{\text {hitung }}$ dengan $r_{\text {tabe4l }}$ setelah dikonsultasikan pada nilai product moment dengan $\mathrm{db} / \mathrm{df}=34$ pada taraf signifikan $5 \%$ didapat $\mathrm{r}$ tabel $=0,339$ sedangkan pada taraf signifikan 1\% diperoleh $r$ tabel $=0,436$. Dengan demikin maka $r$ hitung lebih besar daripada $r_{\text {tabel. }}(0,9314>0,339)$ untuk taraf signifikan $5 \%$ dan $(0,959>$ $0,436)$ untuk taraf signifikan $1 \%$. Ini berarti hipotesis alternatif $\left(\mathrm{H}_{\mathrm{a}}\right)$ diterima atau terbukti kebenarannya, bahwa ada hubungan antara pengetahuan kebahasaan (variabel $\mathrm{X}$ ) dan kemampuan menulis naskah drama berdasarkan pengalaman pribadi (variabel Y) siswa kelas XI SMA Negeri 1 Lubuklinggau. Berdasarkan hasil penelitian dan pembahasan maka dapat disimpulkan bahwa terdapat hubungan antara pengetahuan kebahasaan dan kemampuan menulis naskah drama berdasarkan pengalaman pribadi siswa kelas XI SMA Negeri 1 Lubuklinggau.
\end{abstract}

Kata Kunci : Pengetahuan Kebahasaan, Drama, Pengalaman Pribadi

\section{ABSTRACT}

The purpose of this research is to know correlation of linguistic knowledge with the ability to write drama script based on personal experience of class XI students of SMA Negeri 1 Lubuklinggau. This research uses descriptive correlation method. The data was collected by using two variable test. The variables in this study consist of variables $(X)$ language knowledge $(Y)$ ability to write drama script based on personal experience. To know how the relationship between linguistic knowledge with the ability to write drama script based on personal experience of students of class XI SMA Negeri 1 Lubuklinggau, using the Product Moment formula rough figures. Hypothesis testing by 
comparing the amount of $r$ count with rtabe4l after consulted on product moment value with $d b / d f=34$ at 5\% significant level obtained $r$ table $=0,339$ while at significant level $1 \%$ obtained $r$ table $=0,436$. With demikin then $r$ count is bigger than $r$ table. (0.9314> 0.339) for a significant level of 5\% and (0.959>0.436) for a significant level of $1 \%$. This means that the alternative hypothesis $(\mathrm{Ha})$ is accepted or proved to be true, that there is a correlation between linguistic knowledge (variable X) and the ability to write drama script based on personal experience ( $Y$ variable) students of class XI SMA Negeri 1 Lubuklinggau. Based on the results of research and discussion it can be concluded that there is a relationship between linguistic knowledge and the ability to write drama script based on personal experience of students of class XI SMA Negeri 1 Lubuklinggau.

Keywords: Linguistic Knowledge, Drama, Personal Experience

\section{PENDAHULUAN}

Pembelajaran bahasa Indonesia mencangkup kemampuan kognitif, afektif, dan fisikomotor. Pembelajaran Bahasa dan Sastra di sekolah mengingat pentingnya bahasa sebagai alat komunikasi, maka dalam pengajaran berbahasa tujuan utamanya adalah agar siswa terampil dalam semua aspek berbahasa yaitu terampil menyimak, berbicara, membaca, dan menulis (Tarigan, 1994). Seiring dengan laju perkembangan ilmu pengetahuan dan teknologi maka keempat keterampilan tersebut memegang peranan penting dan strategis. Dalam berbagai kesempatan acapkali keterampilan berbahasa seseorang diuji melalui empat keterampilan tersebut.

Keterampilan menulis sebagai salah satu cara berkomunikasi dapat diartikan sebagai kemampuan seseorang dalam menyampaikan maksud kepada orang lain atau pembaca dengan menggunakan bahasa tulis yang baik dan benar sehingga apa yang ditulis dan disampaikan sesuai dengan apa yang diinginkan penulis.

Begitu besarnya peran kemampuan menulis, wajar apabila kemampuan menulis mendapat perhatian yang mendasar di samping keterampilan membaca. Hal ini dipertegas oleh Arsyad (1982) yang mengatakan tradisi menulis tidak saja harus dibina dan ditingkatkan secara merata, tetapi juga diharapkan kepada penulisan karya-karya besar, agar kebiasaan dan keterampilan menulis dibina secara berkesinambungan. Materi sastra acapkali diberikan kepada siswa dalam bentuk teori, berupa sejarah sastra, definisi, jenis, dan contoh karya sastra. Siswa jarang diberikan pengalaman 
mengapresiasi dan menciptakan langsung karya sastra, baik dalam bentuk puisi, cerpen, maupun drama.

Karya sastra menceritakan kehidupan manusia dan peristiwa-peristiwa yang terjadi di alam sekitar. Pesan atau amanat yang hendak disampaikan dimanifestasikan atau diwujudkan oleh sastrawan melalui perbuatan, tindakan, dan prilaku manusia yang digambarkan lewat tokoh-tokoh yang dianggap mewakili pikiran, ide, atau gagasan yang dimaksud. Hal ini dijelaskan Wellek dan Warren (1995) bahwa sastra adalah "suatu kreatifitas karya seni".

Faktor yang sebenarnya merupakan tantangan bagi guru Bahasa dan Sastra Indonesia dalam pengajaran sastra, khususnya menulis drama adalah bahwa pembelajaran sastra yang ditempatkan sebagai bagian dari pembelajaran Bahasa dan Sastra Indonesia lebih cenderung kurang diperhatikan. Para pengajar hanya mengadopsi sekaligus mengadaptasi berbagai karya yang ada, misalnya dari koran, majalah, atau buku-buku sastra sebagai bahab ajar. Sementara siswa hanya "membaca" karya sastra tersebut kemudian menjawab pertanyaan yang sudah disiapkan berkaitan dengan isi karya sastra tersebut. Drama sebagai bagian dari sastra, dalam pembelajaran juga mendapat perlakuan yang sama. Drama hanya dibaca, peserta didik (siswa) diminta untuk menjawab pertanyaan atau soal-soal.

Berdasarkan hasil pengamatan penulis terhadap kemampuan menulis naskah drama hasil pengalaman pribadi siswa kelas XI SMA Negeri 1 Lubuklinggau masih rendah. Hal ini terjadi karena guru menjadi penguasa kelas. Ceramah menjadi pilihan utama untuk mengajarkan materi. Yang terjadi kemudian adalah adalah situasi kelas kurang produktif karena guru menjadi satu-satunya sumber pengetahuan.

Salah satu cara membuat kelas lebih hidup dan siswa lebih aktif, yakni dengan mendorong siswa berlatih untuk menulis kreatif. Banyak hal yang dapat dijadikan bahan tulisan. Salah satunya adalah menulis naskah drama berdasarkan pengalaman pribadi. Dalam sebuah tulisan kisah atau cerita selalu memiliki bagan atau kerangka. Menurut Puji (2008) bagan tersebut adalah (1) Pembukaan atau pengantar/prolog (sebab), (2) Isi (pemaparan-konflik-klimaks-antiklimaks),(3)Penutupataupenyelesaian/epilog (keputusan/akibat). 
Drama menurut Tukan (2006) merupakan pengalaman hidup manusia yang dipentaskan (di atas panggung) di hadapan orang banyak. Penulisan naskah drama berbeda dengan penulisan cerpen atau novel. Dalam naskah drama, penuturan ceritanya mengutamakan dialog atau percakapan antar tokoh. Dari percakapan antar tokoh itulah penikmat atau pembaca akan menangkap dan memahami isi ceritanya. Puji (2008) menyatakan bahwa secara umum, jenis drama dapat dikelompokkan menjadi empat jenis, yaitu (1) Tragedy (drama duka), (2) Komedi (drama ria/jenaka), (3) Melodrama dan (4) Dagelan (farce)

Berdasarkan uraian di atas, untuk mengetahui lebih jauh hubungan antara pengetahuan kebahasaan dan kemampuan menulis naskah drama berdasarkan pengalaman pribadi penulis perlu mengadakan penelitian ini. Untuk itu penulis memberi judul "Hubungan Pengetahuan Kebahasaan dengan Kemampuan Menulis Naskah Drama Berdasarkan Pengalaman Pribadi Siswa Kelas XI SMA Negeri 1 Lubuklinggau”.

\section{METODE PENELITIAN}

Penelitian ini menggunakan rancangan atau desain penelitian deskriptif korelasional. Penelitian deskriptif korelasional adalah pendekatan deskriptif yang mendeskripsikan dan menginterprestasikan koefisien yang diperoleh dari analisis data yang diperoleh dari analisis data, yang bertujuan untuk menemukan bagaimana hubungan antar dua variabel (Arikunto, 2006).

Dalam penelitian ini ada dua variabel yang digunakan, yaitu variabel $\mathrm{X}$ (pengetahuan kebahasaan) dan variabel $\mathrm{Y}$ (kemampuan menulis naskah drama berdasarkan pengalaman pribadi). Untuk memperoleh data guna mengetahui adakah hubungan antara dua variabel tersebut, peneliti menggunakan teknik tes dan nontes. Teknik tes pilihan ganda untuk variabel $\mathrm{X}$ (pengetahuan kebahasaan) dan tes esai untuk variabel Y (kemampuan menulis naskah drama berdasarkan pengalaman pribadi). Teknik nontes berupa wawancara terhadap guru mata pelajaran Bahasa Indonesia.

Populasi penelitian ini adalah semua siswa kelas XI SMA Negeri 1 Lubuklinggau yang terdiri dari 5 kelas. Sampel penelitian yang diperoleh adalah: $15 \%$ X $239=35,85$ dibulatkan menjadi 36 orang. Sampel penelitian ini diambil dengan 
menggunakan teknik random yaitu dengan cara mencampur populasi sehingga semua subjek dianggap sama.

Data yang digunakan dalam penelitian ini adalah data kuantitatif, yaitu data yang berupa angka-angka yang didapat dari skor nilai pengetahuan kebahasaan (Varibel X) dan kemampuan menulis naskah drama berdasarkan pengalaman pribadi (variabel Y).

Teknik tes yang digunakan dalam mengumpulkan data mengenai pengetahuan kebahasaan pada siswa kelas XI SMA Negeri 1 Lubuklinggau yaitu melalui tes objektif yang berupa pilihan ganda. Tes pilihan ganda yang diterapkan dalam mengumpulkan data mengenai pengetahuan kebahasaan berupa instrumen atau bentuk soal pilihan ganda yang berjumlah 20 soal dengan alternatif jawaban a, b, c, dan d. Untuk jawaban yang benar diberi skor 5 sedangkan jawaban yang salah diberi skor 0. Jika jawaban seluruhnya benar diberi skor 100.

Untuk menentukan skor/nilai tes kemampuan siswa dalam pengetahuan kebahasaan dan keterampilan menulis naskah drama berdasarkan pengalaman pribadi, rumus yang digunakan untuk menetapkan nilai kedua variabel di atas adalah sebagai berikut:

$$
\mathrm{N}=\frac{\text { Skor Perolehan }}{\text { Skor Maksimum }} \times 100 \% \text { (Depdiknas, 2004) }
$$

Pada teknik nontes, peneliti menggunakan tes wawancara (interview). Wawancara ini ditujukan kepada guru yuang mengajar pelajaran Bahasa Indonesia pada SMA Negeri 1 Lubuklinggau.

Keabsahan ini juga dapat dicapai dengan proses pengumpulan data yang tepat. Salah satu caranya adalah dengan proses triangulasi, yaitu tehnik pemeriksaan keabsahan data yang memanfaatkan sesuatu yang lain di luar data itu untuk keperluan pengecekan atau Sebagai pembanding terhadap data itu. Menurut Patton (dalam Sudjiono, 2009) ada 3 macam triangulasi sebagai teknik pemeriksaan untuk mencapai keabsahan, yaitu (1) Triangulasi data, menggunakan berbagai sumber data seperti dokumen, arsip, hasil wawancara, hasil observasi atau juga dengan mewawancarai lebih dari satu subjek yang dianggap memeiliki sudut pandang yang berbeda.(2) Triangulasi Pengamat, adanya pengamat di luar peneliti yang turut memeriksa hasil pengumpulan 
data. (3) Triangulasi Metode, penggunaan berbagai metode untuk meneliti suatu hal, seperti metode wawancara dan metode observasi.

Penelitian ini diarahkan untuk membuktikan bagaimana hubungan dua variabel yaitu pengetahuan kebahasaan (variabel $\mathrm{X}$ ) dan kemampuan menulis naskah drama berdasarkan pengalaman pribadi (variabel Y) kelas X SMA Negeri 1 Lubuklinggau. Langkah terakhir setelah menetapkan skor dan persentase hasil tes adalah mencari korelasi antara pengetahuan kebahasaan (variabel X) dan kemampuan menulis naskah drama berdasarkan pengalaman pribadi (variabel Y). Berikut ini adalah rumus yang digunakan untuk mengkorelasikan data kedua variabel tersebut.

$$
r_{x y}=\frac{n\left(\sum X Y-\left(\sum X\right)\left(\sum Y\right)\right)}{\sqrt{\left\{n\left(\sum X^{2}\right)-\left(\sum X\right)^{2}\right)\left(n\left(\sum Y^{2}\right)-\left(\sum Y\right)^{2}\right\}}} \quad \text { (Sudijono, 2009:206) }
$$

Keterangan :

$\mathrm{r}_{\mathrm{xy}} \quad$ : Angka indeks korelasi " $\mathrm{r}$ " product moment

$\mathrm{N} \quad$ : Jumlah sampel

$\mathrm{X}$ : Skor pengetahuan kebahasaan

$\mathrm{Y} \quad$ : Skor kemampuan menulis naskah drama berdasarkan pengalaman pribadi

$\mathrm{X}^{2}$ : Kuadrat skor pengetahuan kebahasaan

$\mathrm{Y}^{2}$ : Kuadrat skor kemampuan menulis naskah drama berdasarkan pengalaman pribadi

Analisis yang dilakukan diantaranya dengan membandingkan $r_{\text {hitung dengan }} r_{\text {tabel }}$ yang bertaraf signifikan 5\% dan bertaraf signifikan 1\%. Hipotesis akan ditolak jika harga $\mathrm{r}$ yang diperoleh dari hasil perhitungan lebih kecil dari harga $\mathrm{r}$ di dalam tabel. Hipotesis diterima bila $r_{\text {hitung }}$ lebih besar atau sama dengan $r_{\text {tabel }} \cdot H_{a}$ diterima jika $r_{x y} \geq r$ tabel baik pada signifikan $5 \%$ dan $1 \%$.

\section{HASIL PENELITIAN}

Penelitian yang dilaksanakan 22 Februari 2011 sampai dengan 12 Maret 2011 diri hasil Data yang diperoleh dari hasil penelitian, yaitu berupa data kuantitatif dalam bentuk tes objektif pengetahuan kebahasaan yang berjumlah 20 soal. Data ini diambil setelah penulis menerangkan pembelajaran tentang pengetahuan kebahasaan. Dalam kegiatan pembelajaran ini penulis terlebih dahulu menjelaskan kepada siswa mengenai 
definisi dan teori kebahasan, setelah itu guru menyuruh siswa untuk menjawab soal pilihan ganda yang telah disediakan.

Untuk lebih jelasnya mengenai rekapitulasi nilai pengetahuan kebahasaan siswa dapat distribusi frekuensi di bawah ini :

$$
\begin{aligned}
& \mathrm{H}=90 \\
& \mathrm{~L}=50 \\
& \mathrm{R}=\mathrm{H}-\mathrm{L}+1 \\
& \mathrm{R}=90-50+1=41 \\
& \frac{40}{i}=10 \rightarrow 20 \\
& i=5
\end{aligned}
$$

Dari hasil perhitungan tersebut dapat ditetapkan i sebesar 5 dan deretan interval yang akan terdapat dalam tabel distribusi frekuensi sebanyak 9 kelas. Berdasarkan tabel distribusi frekuensi di atas nilai penguasaan kalimat efektif siswa secara jelas dapat dijabarkan sebagai berikut jumlah siswa yang memperoleh nilai 90-94 sebanyak 4 orang dan siswa yang memperoleh nilai 85-89 sebanyak 3 orang. Untuk siswa yang memperoleh nilai 80-84 sebanyak 6 orang, siswa yang memperoleh nilai 75-79 sebanyak 10 orang, siswa yang memperoleh nilai 70-74 sebanyak 8 orang, siswa yang memperoleh nilai 65-69 sebanyak 3 orang, siswa yang memperoleh nilai 60-64 sebanyak 1 orang, siswa yang memperoleh nilai 55-59 tidak ada sedangkan siswa yang memperoleh nilai 50-54 sebanyak 1 orang.

Siswa yang memiliki pengetahuan kebahasaan dengan kategori cukup sebanyak 12 orang atau sebanyak 33,33\%. Sedangkan siswa yang memiliki pengetahuan kebahasaan dengan kategori kurang sebanyak 1 orang atau sebanyak 2,78\%.

Dan berdasarkan perhitungan nilai pada tes objektif pengetahuan kebahasaan dari 36 sampel diperoleh jumlah skor 2710 maka nilai rata-ratanya adalah:

$$
N=\frac{2710}{36} \times 100 \%=75,28 \%
$$

Dari hasil perhitungan nilai rata-rata pengetahuan menulis di atas maka nilai rataratanya 75,28 atau $75,28 \%$. Nilai tersebut dikonsultasi dengan skala lima tergolong 
baik. Dengan demikian dapat dikatakan bahwa pengetahuan kebahasaan untuk SMA Negeri 1 Lubuklinggau tahun ajaran 2010/2011 tergolong baik.

Data kemampuan menulis naskah drama berdasarkan pengalaman pribadi diambil setelah penulis menerangkan pembelajaran tentang drama. Setelah siswa menjawab soal yang telah diberikan, guru mengadakan penilaian. Selanjutnya guru membuat rekapitulasi nilai kemampuan menulis naskah drama berdasarkan pengalaman pribadi. Siswa yang memiliki kemampuan menulis naskah drama berdasarkan pengalaman pribadi dengan kategori sangat baik sebanyak 5 orang atau sebanyak 13,89\% dan untuk siswa yang memiliki kemampuan menulis naskah drama berdasarkan pengalaman pribadi dengan kategori baik sebanyak 13 orang atau sebanyak 36,11\%. Sedangkan siswa yang memiliki kemampuan menulis naskah drama berdasarkan pengalaman pribadi dengan kategori cukup sebanyak 18 orang atau sebanyak 50,00\%.

Berdasarkan perhitungan nilai pada tes portofolio kemampuan menulis naskah drama berdasarkan pengalaman pribadi dari 36 sampel diperoleh jumlah skor 2640 maka nilai rata-ratanya adalah:

$$
N=\frac{2640}{36} \times 100 \%=73,33 \%
$$

Hasil perhitungan nilai rata-rata kemampuan menulis naskah drama berdasarkan pengalaman pribadi di atas maka nilai rata-ratanya dalam persentase adalah $73,33 \%$. Dengan demikian dapat dikatakan bahwa kemampuan menulis naskah drama berdasarkan pengalaman pribadi untuk siswa kelas XI SMA Negeri 1 Lubuklinggau Tahun Ajaran 2010/2011 tergolong cukup.

Untuk mengetahui ada atau tidaknya korelasi atau hubungan antara pengetahuan kebahasaan dan kemampuan menulis naskah drama berdasarkan pengalaman pribadi siswa kelas XI SMA Negeri 1 Lubuklinggau digunakan rumus koefisien korelasi product moment yaitu dengan mengkorelasikan antara pengetahuan kebahasaan (variabel $\mathrm{X}$ ) dan kemampuan menulis naskah drama berdasarkan pengalaman pribadi (variabel Y).

Berdasarkan hasil perhitungan, maka diperoleh $r_{x y}=0,931$. Nilai ini bila dikonsultasikan pada tebel " $r$ " Pruduct Moment dengan derajat kebebasan $=36-2=34$ pada taraf signifikan $5 \%$ diperoleh $r_{\text {tabel }}=0,339$, sedangkan pada taraf 
signifikan $1 \%$ diperoleh $r_{\text {tabel }}=0,436$. Hal ini berarti bahwa nilai $r_{\text {hitung }}>r_{\text {tabel }}$ baik pada taraf signifikan 5\% maupun taraf signifikan $1 \%$.. Dengan demikin maka $\mathrm{r}_{\text {hitung }}$ lebih besar daripada $r_{\text {tabel, }}(0,931>0,339)$ untuk taraf signifikan $5 \%$ dan $(0,931>0,436)$ untuk taraf signifikan $1 \%$. Ini berarti hipotesis alternatif $\left(\mathrm{H}_{\mathrm{a}}\right)$ diterima atau terbukti kebenarannya, bahwa ada hubungan antara pengetahuan kebahasaan (variabel X) dan kemampuan menulis naskah drama berdasarkan pengalaman pribadi (variabel Y) siswa kelas XI SMA Negeri 1 Lubuklinggau.

Pengujian hipotesis dengan membandingkan besarnya $r_{\text {hitung }}$ dengan $r_{\text {tabel }}$ setelah dikonsultasikan pada nilai $\mathrm{r}$ product moment dengan $\mathrm{db} / \mathrm{df}=34$ pada taraf signifikan $5 \%$ didapat $r_{\text {tabel }}=0,339$, sedangkan pada taraf signifikan $1 \%$ diperoleh $r_{\text {tabel }}=0,436$. Hal ini berarti bahwa nilai $r_{\text {hitung }} \geq r_{\text {tabel }}$ baik taraf signifikan $5 \%$ maupun pada taraf signifikan $1 \%$.

\section{PEMBAHASAN}

Dengan demikin maka $r_{\text {hitung }}$ lebih besar daripada $r_{\text {tabel, }}(0,931>0,339)$ untuk taraf signifikan $5 \%$ dan $(0,931>0,436)$ untuk taraf signifikan $1 \%$. Ini berarti hipotesis alternatif $\left(\mathrm{H}_{\mathrm{a}}\right)$ diterima atau terbukti kebenarannya, bahwa ada hubungan antara pengetahuan kebahasaan (variabel $\mathrm{X}$ ) dan kemampaun menulis naskah drama berdasarkan pengalaman pribadi (variabel Y) siswa kelas XI SMA Negeri 1 Lubuklinggau. Berdasarkan hasil penelitian dari 36 sampel rata-rata hasil tes objektif pengetahuan kebahasaan secara keseluruhan adalah 75,28\% dengan skor tertinggi 90 dan skor terendah 50. Ini berarti secara keseluruhan dapat dikatakan bahwa siswa kelas kelas XI SMA Negeri 1 Lubuklinggau memiliki skor pengetahuan kebahasaan yang baik.

Hasil penelitian tes fortofolio secara kuantitatif tentang keterampilan menulis naskah drama berdasarkan pengalaman pribadi, secara keseluruhan siswa kelas XI SMA Negeri 1 Lubuklinggau dari 36 sampel hasil keseluruhan adalah 73,33\% dengan skor tertinggi 90 dan skor terendah 60. Ini berarti secara keseluruhan dapat dikatakan bahwa keterampilan menulis naskah drama berdasarkan pengalaman pribadi siswa kelas XI SMA Negeri 1 Lubuklinggau memiliki keterampilan menulis naskah drama berdasarkan pengalaman pribadi yang cukup. 
Dalam melengkapi data pada penelitian ini peneliti juga melakukan wawancara kepada guru yang mengajar mata pelajaran Bahasa dan Sastra di XI SMA Negeri 1 Lubuklinggau. Dari wawancara yang telah dilakukan, peneliti memperoleh data bahwa pelajaran pengetahuan kebahasaan dan keterampilan menulis naskah drama berdasarkan pengalaman pribadi di kelas XI SMA Negeri 1 Lubuklinggau.

Problem dalam pembelajaran hanya sedikit yakni kurangnya jam tatap muka pada materi ini. Sedangkan siswa yang mengalami kesulitan ada tapi tidak prinsip.

Berdasarkan hasil analisis deskriptif tentang hubungan pengetahuan kebahasaan dan menulis naskah drama berdasarkan pengalaman pribadi kelas XI SMA Negeri 1 Lubuklinggau Tahun Ajaran 2010/2011 ternyata memiliki hubungan yang signifikan. Ini berarti siswa yang memiliki pengetahuan kebahasaan dengan baik juga memiliki kemampuan menulis naskah drama berdasarkan pengalaman pribadi yang cukup.

Demikian juga sebaliknya jika pengetahuan kebahasaan jelek maka kemampuan menulis naskah drama berdasarkan pengalaman pribadi tidak baik. Hal ini dapat dilihat dari hasil perhitungan statistik bahwa antara pengetahuan kebahasaan dan keterampilan menulis naskah drama berdasarkan pengalaman pribadi terdapat hubungan yang signifikan yaitu $r_{\text {hitung }}=0,931$ lebih besar daripada nilai $r_{\text {tabel }}$ baik pada taraf signifikan 5\% (0,334) maupun pada taraf signifikan 1\% (0,487) dengan derajat kebebasan 34.

Dengan demikian hipotesis yang berbunyi "terdapat hubungan yang signifikan antara pengetahuan artikel dan kemampuan memahami artikel harian linggau pos siswa kelas X SMA Negeri 4 Lubuklinggau tahun ajaran 2010/2011” dapat diterima.

\section{SIMPULAN}

Berdasarkan hasil penelitian dan pembahasan maka dapat disimpulkan bahwa ada hubungan signifikan antara pengetahuan kebahasaan dan kemampuan menulis naskah drama berdasarkan pengalaman pribadi siswa kelas XI SMA Negeri 1 Lubuklinggau.Berdasarkan rekapitulasi nilai rata-rata untuk penguasaan kebahasaan yaitu 75,28 (75,28\%). Nilai tersebut jika dikonsultasikan dengan tolak ukur terletak pada interval 75\%-84\% dengan kategori baik.Sedangkan rekapitulasi nilai rata-rata kemampuan menulis naskah drama berdasarkan pengalaman pribadi di dapat nilai rataratanya dalam persentase adalah $73,33 \%$. Nilai tersebut jika dikonsultasikan dengan 
skala lima tergolong cukup. Berdasarkan hasil analisis perhitungan, maka diperoleh $\mathbf{r}_{\mathrm{xy}}$ $=0,9314$. Nilai ini bila dikonsultasikan pada tebel "r" Pruduct Moment dengan derajat kebebasan $\mathrm{N}-2=36-2=34$ pada taraf signifikan 5\% diperoleh $\mathrm{r}_{\text {tabel }}=0,339$, sedangkan pada taraf signifikan $1 \%$ diperoleh $r_{\text {tabel }}=0,436$. Hal ini berarti bahwa nilai $r_{\text {hitung }}>r_{\text {tabel }}$ baik pada taraf signifikan $5 \%$ maupun taraf signifikan $1 \%$. Dengan demikian ada hubungan signifikan antara pengetahuan kebahasaan dan kemampuan menulis naskah drama berdasarkan pengalaman pribadi siswa kelas XI IPA SMA Negeri 1 Lubuklinggau.

\section{DAFTAR PUSTAKA}

Arikunto, Suharsimi. (2006). Prosedur Penelitian Suatu Pendekatan Praktek. Jakarta: Rineka Cipta.

Arsyad. (1982). Kemampuan Menulis Bahasa Indonesia. Jakarta: Erlangga.

Depdiknas. (2004). Petunjuk Pelaksanaan Sistem Penilaian. Jakarta: Depdiknas.

Puji, P. (2008). Mengenal Teknik Menulis Drama. Jakarta: Citra Aji Pratama

Sudijono, Anas. (2009). Pengantar statistik Pendidikan. Jakarta: Rajawali Pers.

Tarigan, Henry Guntur. (1994). Menulis Sebagai Suatu Keterampilan Berbahasa. Bandung: Angkasa.

Tukan, Paulus. (2006). Mahir Bahasa Indonesia. Jakarta: Yudistira.

Wellek dan Austin Warren. (1995). Teori Kesusastraan. Jakarta: PT. Gramedia. 